\author{
BULETINUL INSTITUTULUI POLITEHNIC DIN IAŞI \\ Publicat de \\ Universitatea Tehnică „Gheorghe Asachi” din Iaşi \\ Volumul 67 (71), Numărul 4, 2021 \\ Secţia \\ CONSTRUCŢII DE MAȘINI \\ DOI: $10.2478 /$ bipcm-2021-0026 \\ sciendo
}

\title{
INITIAL CONSIDERATIONS IN THE STUDY OF THE MANUFACTURING PROCESS BY ELECTROCHEMICAL MACHINING
}

BY

\section{DANIELA GABRIELA CIOBANU (IORGOAIA)*}

"Gheorghe Asachi" Technical University of Iaşi, Romania, Faculty of Machine Manufacturing and Industrial Management

Received: October 1, 2021

Accepted for publication: December 14, 2021

\begin{abstract}
Electrochemical machining relies on the electrolysis phenomenon, this being characterized by the chemical reaction between the workpiece material and an electrolyte solution. Both the electrode and the workpiece materials are connected into an electric circuit, charged by a direct current electric energy source. The workpiece is used to get some complex forms of cavities into parts of electrically conductive materials or other hard conductive materials, which could not be processed efficiently by the other means. This paper presents the results of some research related to the development of an equipment concept that could highlight the variation of some output parameters of the process in function of the value of the input factors in the process. It has opted to create a device for studying electrochemical erosion, where different substances, with a direct current source with variable adjustment. Taking into account the experimental results when using different materials for the workpiece, different materials for the tool electrode, many working electrolyte type substances, and changing the values of the electrical parameters, results necessary for a relevant conclusion could be obtained.
\end{abstract}

Keywords: unconventional technologies; electrochemical erosion; processing equipment; input factors; output parameters.

*Corresponding author; e-mail: danielaciobanu73@yahoo.com

This is an open access article licensed under the Creative Commons Attribution-NonCommercialNoDerivatives 4.0 International License (CC BY-NC-ND 4.0). 


\section{Introduction}

The processing of metallic materials using unconventional technologies to obtain some products appeared as an objective, complementary, essential, and sometimes unique necessity, together with the classical technologies.

Metal processing to obtain finished parts is performed by plastic deformation processes (rolling, forging, drawing, extrusion), cutting processes (turning, planning, milling, drilling, reaming, etc.), but also by modern, unconventional processes of processing (chemical machining, electrical discharge machining, plasma processing, laser processing, electron beam machining, ultrasonic machining, etc.). The unconventional technologies known and used today are electro erosion processing, electrochemical erosion processing, chemical erosion processing, electrochemical and electrical erosion processing, plasma erosion processing, radiation erosion processing, and ultrasonic erosion processing (Dodun, 2001; Gavrilas and Marinescu, 1991; Slătineanu, 2001).

The processing by electrochemical erosion is based on the phenomenon of anodic dissolution, i.e., the passage of the workpiece material into electrolyte solution by some simple chemical reactions. The main advantages of the electrochemical machining are the followings: processing productivity is high; dimensional accuracy and quality of machined surfaces could be acceptable; processing does not lead to structural changes or surface stresses in the machined parts; the possibility of obtaining parts to the final shape, without further processing (Nagît, 1998).

The productivity of electrochemical processing is the amount of material chemically dissolved under the action of electric current in the unit of time. Based on Faraday's laws, the actual amount of metal eroded from the anode can be approximated.

Also, the processing by electrochemical erosion processes could be classified as follows: electrochemical erosion with natural depassivation, electrochemical erosion with hydrodynamic depassivation and abrasive electrochemical erosion with abrasive depassivation.

The Englishmen Humphry Davy (1778-1829) and Michael Faraday (1791-1867) laid the foundations of electrochemical science. The emergence of electrochemical processing was favoured by the formulation of the laws of electrolysis.

According to these laws (established by Michael Faraday), if the metal to be processed is placed at the anode, and the tool electrode at the cathode, between them being fond an electrolyte, generally consisting of a solution of salts, when applying continuous voltage, the metal at the anode is dissolved (anodic dissolution). The detached material moves in solution or is deposited on the cathode. 
However, in the 1950s, electrochemical processing methods became methods applied in industry, first in the United States of America (known as "electrochemical machining"), then after 1960 in European countries and Japan. This method gained widespread use gradually, needing more and more complex processing equipment and allowing obtaining higher productivity, in the conditions in which the quality of the processed surfaces is most of the times at least acceptable (Dodun, 2001; El Hofy, 2019).

By electrochemical processing, parts can be obtained at the final level, without further processing, the part lacking the surface stresses induced in conventional processing due to structural transformations during the process.

\section{The Outline of an Equipment Solution for the Study of the Electrochemical Erosion Process}

Based on the information identified in the literature and taking into account the needs of design and materialization of an equipment for the study of the electrochemical erosion process, it was decided to develop an equipment having on the base a tank made out of a material that allows direct observation of the process (similar tank, from this point of view, as that of an aquarium with transparent walls), in which the electrolyte solution will be placed (i.e., aqueous solutions of some salts, acids, etc.).

A direct electric current with variable regulation was considered to be applied to use a transformer - rectifier group for this purpose, supplied from the electricity network. As test pieces, parallelepiped-shaped samples of different metallic materials shall be used, leaving a single surface uncovered by a protective layer intended to direct the action of the process only towards this surface. These test pieces will all have the same geometric shape and approximately the same weight. A part of copper will be used as a tool electrode, as it is not usually affected by any weight loss. The tool electrode and the workpiece will be connected to the direct current electric source through electrical conductors. An ammeter and a voltmeter will also be inserted in the circuit to obtain direct information on the values of some of the input factors in the process. It is intended that the test pieces be kept in the electrolyte for predetermined intervals. Both during the electrochemical erosion process, the values of some process output parameters will be monitored. A simplified scheme of operation of the equipment can be seen in Fig. 1. 


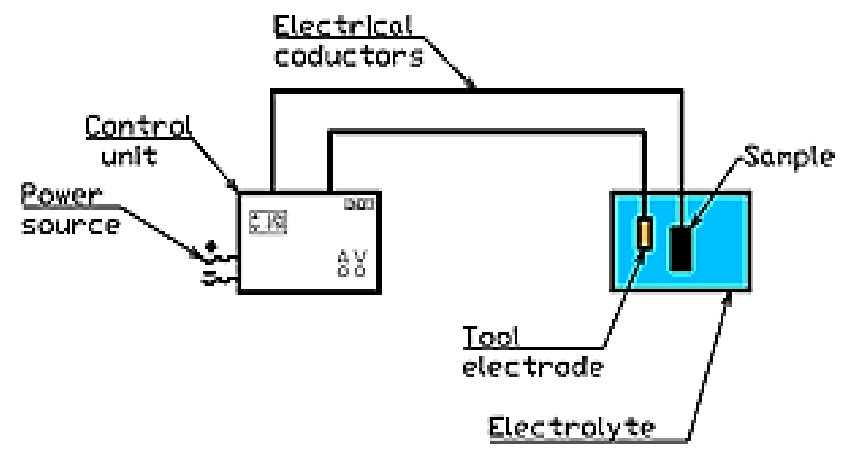

Fig. 1 - Simplified operation scheme of the proposed equipment for conducting experimental research on the process of electrochemical machining.

\section{Theoretical Approaches of the Electrochemical Erosion Process}

For the theoretical modeling of some specific aspects of the electrochemical erosion process, the starting point was designing a system corresponding to the physical model of the process under investigation (Ciobanu et al., 2021). An initial systemic analysis of the highlighted input factors such as the test piece material nature, the electrolyte solution's nature, the electrolyte solution's concentration and temperature, the intensity of the electric current, etc. The roughness profile, the change of electrolyte solution $\mathrm{pH}$, the productivity of the material removal process, the reduction of the dimensions and the test piece mass, etc. could be considered output parameters. Some of the input factors and output parameters of the process are highlighted in Fig. 2.

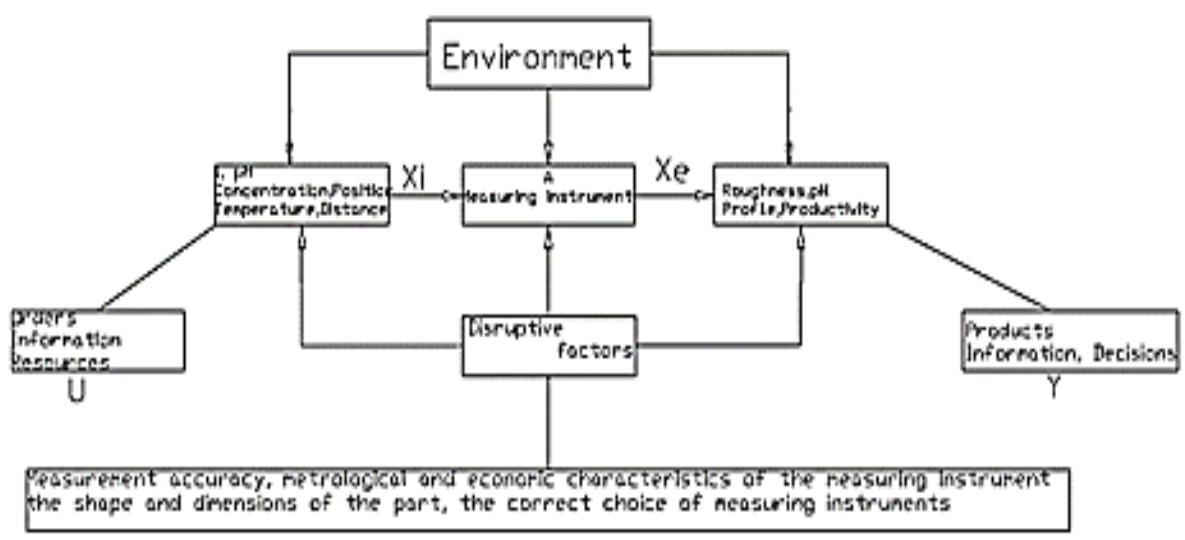

Fig. 2 - The overview of a system. 
The factors (parameters) that characterize the inputs in the researched system, also called input factors or input variables, are the data available at the initial stage of the process. These data are necessary to establish the circumstances in which the experimental research will take place. If we consider $A$ is a matrix type function, between the values of the output parameters $Y$ and the values of the input factors $U$, it could then be written a relation as stated below (Buidos, 2006):

$$
Y=A \cdot U \text {. }
$$

The variation of the output parameter $Y$ when changing $\Delta U$ of an input parameter may make it necessary to add in an operator block $R$ (Buidoş, 2006):

$$
\Delta U=R \cdot Y .
$$

The disturbing factors alter the normal operability of the system but whose values can be neither predicted nor controlled. The external environment and the human factors are the main factors that can change the system's functioning (Nagît, 1998).

The external environment can influence the result through the temperatures that can generate expansion or contraction phenomena, through vibrations, the eventual radiation that could modify the circumstances of the process, etc.

The human factor can also introduce errors due to lack of attention, decreased visibility acuity, insufficient experience in the professional field, etc.

The output parameters are measurable parameters whose values are expected to change in every experimental test.

These outputs are also called results, response variables, or output variables, all these providing the whole picture of the recorded results.

It is mandatory to ensure that:

- The actual result should mean the achievement of the proposed objective for the experimental research;

- The response should be easily measurable;

- The result should be an unambiguous correlation between the influencing factors and the chosen output parameters. the following:

- Electrical parameters, such as the corresponding current and the average voltage of the pulse generator, and also some pulse parameters, when using pulse electrochemical erosion processing (pulse duration and pause state, duration between two pulses, pulse frequency, waveform of the pulse, etc.) (Dodun, 2001); 
- Test piece material properties and the material properties from which the tool electrode is made. It is necessary to take into account some magnetic, chemical, physical properties, the structure of those materials;

- The process duration that ensures the obtaining of certain processed surface roughness by electrochemical erosion;

- The properties of the electrolyte solution (of the working liquid substance), such as chemical composition, concentration, viscosity, electrical resistance, boiling temperature, etc.;

- The contact with atmospheric air and the dissolution degree in the electrolyte solution. Such factors can affect the electrical resistance of the electrolyte and can influence the characteristics of the surface processed by electrochemical erosion.

The output factors that can be considered are the following:

- In a time unit, the eroded material quantity from electrodes following the processing by electrochemical erosion. This feature highlights, for instance, the behavior of the test piece material in the electrochemical erosion process. The behavior of the tool electrode material could also be considered, and it is possible to determine in this way whether the material can be used in the system under investigation (Gavrilaș and Marinescu, 1991);

- The machining accuracy can be highlighted by the extent to which processing can reach certain dimensions of the processed surface, obviously in the case of those surfaces that have not been covered with any protective layer;

- The surface roughness; represents an important output parameter of electrochemical erosion processing, sometimes being a decisive aspect, based on which we can evaluate the ability to achieve certain objectives in the case of the equipment addressed here;

- The processing speed, with their aid, the time needed to obtain an optimal result and to observe whether the system has sufficiently high productivity compared to the initial assumptions can be determined.

By designing and materializing experimental tests on the equipment mentioned above type, it will be possible to investigate the behavior of different materials in the case of electrochemical erosion processing and eventually to establish an empirical mathematical model able to provide information on the intensity of influence exerted by these input factors on the values of some of the output parameters of the process. 


\section{Conclusions}

The application of the electrochemical erosion processing method has some advantages, including that the process results are not conditioned by the hardness of the workpiece material or the shape of the profile to be processed, that surfaces with complex shapes and high precision can be obtained, that the surface layer processed may have different properties from those of the use of classical processes, that in the process do not develop significant forces that would involve deformations of the technological system components. The analysis of some information identified in the literature allowed a clarification for both input factors and output parameters of the electrical erosion processing and the outline of general information regarding the structure of equipment designed to allow the study of this electrochemical erosion processing.

\section{REFERENCES}

Buidos T., Echipamente și tehnologii pentru prelucrări neconvenționale, University Publishing House, Oradea, 2006.

Ciobanu (Iorgoaia) D.G., Ciobanu A.C., Misăilă A., Abordare preliminară în studiul procesului de prelucrare prin eroziune electrochimică, available at http://repository.utm.md/handle/5014/16248, accessed: 20.11.2021.

Dodun O., Tehnologii neconvenționale. Prelucrări cu scule materializate, Technica Info Publishing House, Chișinău 2001.

El-Hofy H., Vibration-Assisted Electrochemical Machining: A Review, Int. J. Adv. Manuf. Techn., 105, 579-593 (2019).

Gavrilaș I., Marinescu N.I., Prelucrări neconvenționale în construcția de mașini, Technical Publishing House, București 1991.

Nagîț G., Tehnologii neconvenționale, "Gheorghe Asachi”" Technical University of Iași, 1998.

Slătineanu L., Tehnologii neconvenționale în construcția de mașini, Technica Info Publishing House, Chișinău, 2001.

\section{CONSIDERAȚII INIȚIALE ÎN STUDIUL PROCESULUI DE FABRICAȚIE PRIN EROZIUNE ELECTROCHIMICĂ}

(Rezumat)

Prelucrarea electrochimică se bazează pe fenomenul de electroliză, acesta fiind caracterizat prin realizarea reacțiilor chimice între materialul semifabricatului și o soluție de tip electrolit, atât electrodul sculă, cât şi semifabricatul fiind conectate într-un circuit electric alimentat de la o sursă de curent continuu. Prelevarea de 
material din semifabricat prin eroziune electrochimică este utilizată pentru realizarea unor cavităţi de forme complicate în piese din materiale electroconductoare sau din materiale dure, care nu ar putea fi prelucrate eficient prin alte procedee. În prezenta lucrare, se are în vedere prezentarea unor rezultate ale unor cercetări referitoare la conceperea unui echipament care să evidențieze variația unor parametri de ieșire ai procesului în funcție de valorile factorilor de intrare în proces. S-a optat pentru realizarea un dispozitiv pentru studiul procesului de eroziune electrochimică, alcătuit dintr-o cuvă (asemănătoare unui acvariu cu pereți transparenți), unde se vor introduce diferite substanțe de tip electrolit (soluții apoase ale unor săruri, ale unor acizi), o sursă de tensiune continua cu reglare variabilă (de exemplu, un încărcător de baterii auto). Pe baza experimentelor realizate, folosindu-se diverse materiale pentru semifabricate, cu proprietăţi diverse, diferite materiale pentru electrodul sculă, multiple substanțe de lucru și modificarea caracteristicilor electrice cu ajutorul sursei de tensiune, împreună cu datele colectate în urma experimentelor, va fi posibilă stabilirea unor modele matematice empirice, care să ofere informații suplimentare privind desfăşurarea procesului de eroziune electrochimică. 